\title{
Centers of Biomineralization
}

\section{Maciej Pawlikowski*}

Department of Mineralogy, Petrography and Geochemistry, AGH University of Science and Technology, Cracow, Poland

*Corresponding author: Maciej Pawlikowski, Department of Mineralogy, Petrography and Geochemistry, AGH University of Science and Technology, Cracow, Poland, E-mail: mpawlik@agh.edu.pl

Received: 23 Sep, 2021 | Accepted: 15 Oct, 2021 | Published: 22 Oct, 2021

Citation: Pawlikowski M (2021) Centers of Biomineralization. J Surg Open Access 7(5): dx.doi.org/10.16966/2470-0991.253

Copyright: (C) 2021 Pawlikowski M. This is an open-access article distributed under the terms of the Creative Commons Attribution License, which permits unrestricted use, distribution, and reproduction in any medium, provided the original author and source are credited.

\section{Abstract}

This work discusses various genetic types of tissue and organ biomineralization centers. It also addresses the issue of various substances that mineralize tissues and presents the results of attempts to dissolve the already existing biomineralization. Understanding the phenomenon of tissue biomineralization will contribute to its prevention and, if it has already occurred, its elimination.

\section{Introduction}

Biomineralization also known as calcification of tissues and organs is a process that causes many diseases and often leads to death. It has been diagnosed in arteries (including coronary vessels), heart valves, articular cartilage, tendons, skin, gallbladder, kidneys, and even in cancer, etc.

It can manifest as grains, crystals and irregular concretions, and in such cases, it is recognizable even macroscopically. Most often, however, it is hidden. Then, it results from the incorporation of elements into biological structures often damaged tissues. This hidden mineralization may or may not develop further into overt mineralization.

Two factors are necessary for the biomineralization of tissues to occur: the substance mineralizing tissues and the so-called crystallization center.

The excess of crystallizing substances in the tissues is associated with malfunctioning of the organs that produce these substances. For example, elevated cholesterol levels are the result of liver dysfunction, and elevated levels of calcium and phosphorus may be associated with disorders of the PTH, calcitonin, and vitamin D system. There are many such dependencies, dealt with by medicine in the broad sense of the word. The methods used focus on maintaining certain parameters, e.g. blood, urine, etc., within intervals considered as normal.

The second element determining the possibility of tissue biomineralization are crystallization centers. These are places in the tissues where the formation of both hidden and overt mineralization can be initiated. These places are areas of tissues subject to destruction processes. Such destruction, or damage, may result from various causes.

The presented article discusses various causes of the formation of tissue biomineralization centers. It is the result of over 40 years of the author's research and is based on extensive literature [1-51].

\section{Definition of Tissue Biomineralization Center}

Healthy and intact biological structures usually do not have surface electric potential (Figure 1.1). A tissue mineralization center is a place in the tissues where the aforementioned hidden and overt mineralization can develop. Such a place is characterized by the presence of free atomic bonds and is endowed with electric charges. Thanks to this, the center catches nearby electrically charged particles and ions. Once they are attached to the biological structure, the formation of biomineralization begins at the center.

When organic molecules are near the center, organic biomineralization occurs, such as cholesterol deposits.

When inorganic particles are near the center, inorganic biomineralization occurs, e.g. calcifications.

When there are organic and inorganic molecules near the center, they attach to the center and form an organic-inorganic biomineralization (Figure 1.2).

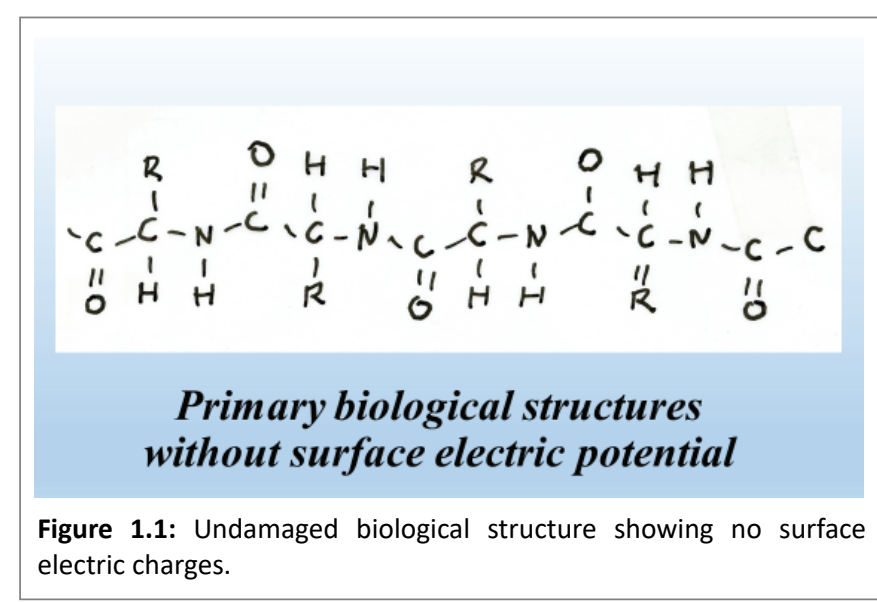



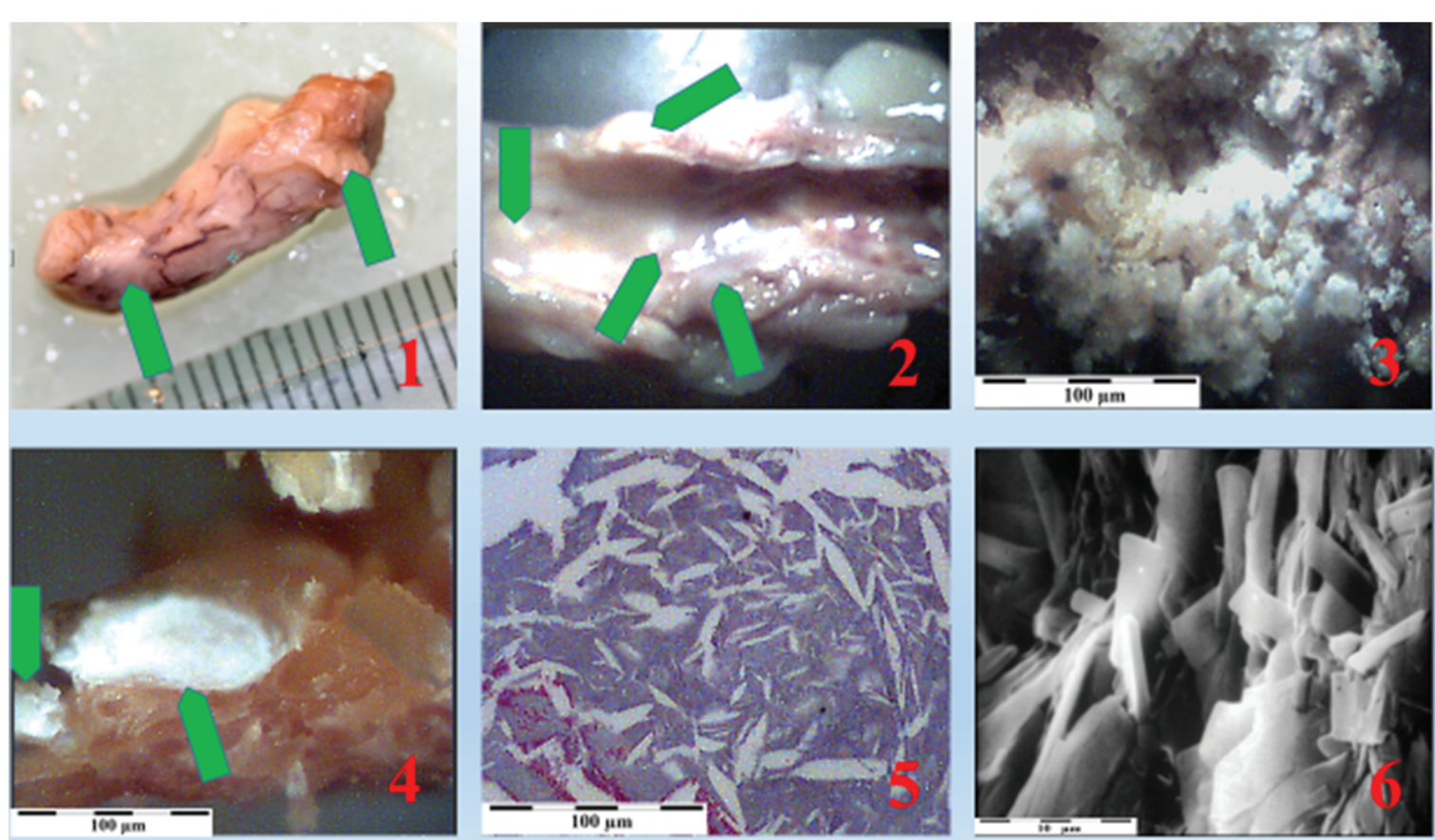

Figure 1.2: Examples of different tissue biomineralization.

1. Phosphate mineralization hardening the wall of the coronary artery (arrows); 2 . Cross-section of the coronary artery with organic-inorganic mineralization concentrations (arrows), Scanning microscope; 3. Inorganic (phosphate) concentration in the cartilage of the hip joint (arrows); 4. A grain of inorganic mineralization in the tendon; 5 . Cholesterol mineralization in the form of boat-shaped crystals in the mass of microcrystalline cholesterol. Polarizing microscope, slide stained with hematoxylin; 6. Microcrystals of inorganic mineralization on the endothelial surface of the artery in the base of the brain. Scanning microscope.

\section{Types of Tissue Biomineralization Centers}

\section{Genetic centers of crystallization}

They are the result of genetic defects that arise in many biological processes. They lead to deformation of atomic structures, e.g. in proteins, and creation of electrically charged sites in these structures (Figure 2.1). These sites are potential centers of crystallization. They can "trap" nearby charged molecules, triggering the initiation of the biomineralization process. They are passed down from generation to generation, causing hereditary tendencies to biomineralization in the same organs.

\section{Crystallization centers resulting from excessive physical exertion}

Another element that destroys tissues is excessive physical exertion exercise, sports, etc. As a result of high stress, tissues, tendons, elements of the heart, arteries, etc. may be damaged. These damaged sites are manifested by broken interatomic bonds, and consequently the formation of crystallization centers with free ionic bonds. They are endowed with electric charges that attract ions from the environment. The attracted ions built into the biological structure of the tissue are the beginning of its biomineralization (Figure 2.2).

\section{Crystallization centers resulting from infection and inflammation}

Microorganisms that infect us produce various types of toxins during their life processes. They are often extremely aggressive and cause disease symptoms. These toxins also affect tissues by damaging their structures (Figure 2.3). The result is breaking of inter atomic bonds in the structures damaged by these toxins, i.e. formation of places that are electrically charged. The field formed around these places is the (attraction) zone for electrically charged ions, i.e. it functions as a crystallization center. In some cases, the body heals such places by itself.

\section{Crystallization centers resulting from environmental contamination}

$$
\begin{array}{ll}
\text { a. } & \text { Food } \\
\text { b. } & \text { Water } \\
\text { c. } & \text { Air } \\
\text { d. } & \text { Radiation (various types) }
\end{array}
$$

Various types of substances introduced into our body with food, water or the air we breathe may lead to destruction of tissues and organs. The phenomenon is well-known, so I will not describe it here. The result of those interactions is damage to the biological structures of various organs (Figure 2.4).

\section{Crystallization Phenomenon in the Crystallization Centers}

\section{Crystallization of organic substances}

In the case when electrically charged cholesterol particles are present in the vicinity of the crystallization center, they bind to the damaged biological structure (Figure 3.1). As a result, a new biological structure is created and the tissues subject to the biomineralization process do not perform their tasks properly. That in turn causes tissue and organ dysfunction. 


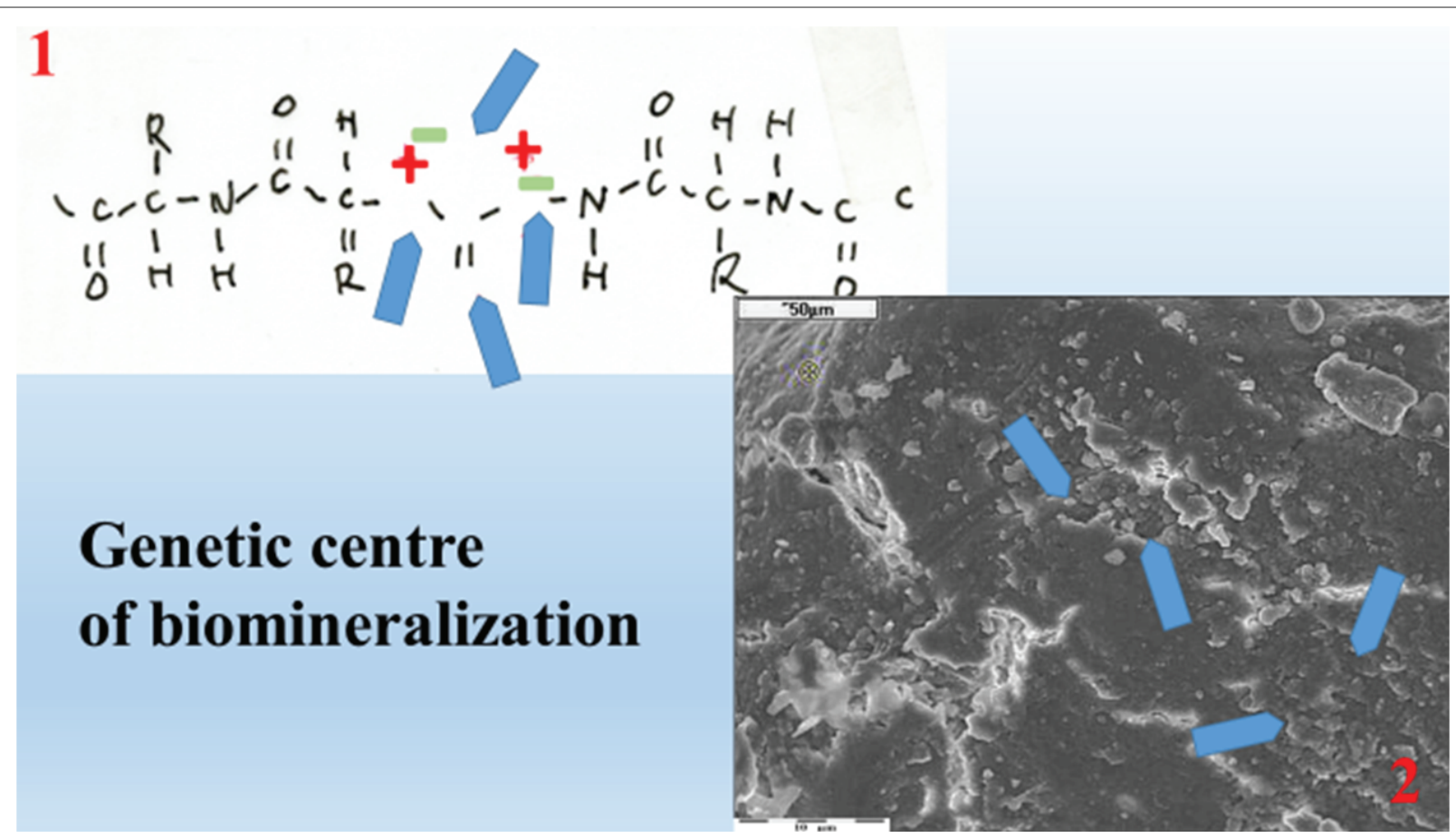

Figure 2.1: 1. Genetically deformed biological structure. Deformation can be passed down from generation to generation, favoring the biomineralization of tissues of the same organ; 2. Micrograph of the endothelial surface of the femoral artery with marked (genetic?) damage sites. Scanning microscope.

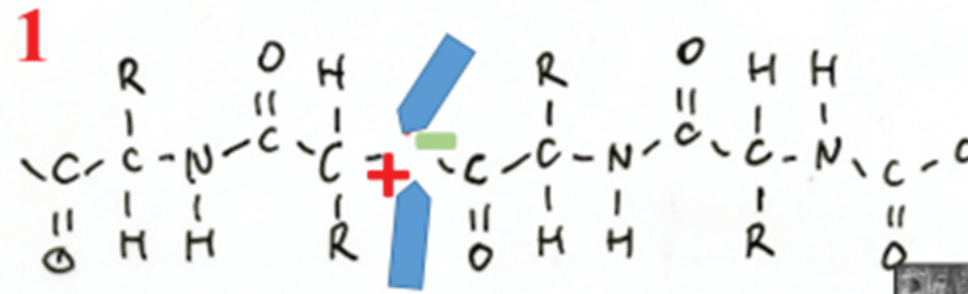

\section{Centre of biomineralization} formed due to mechanical damage

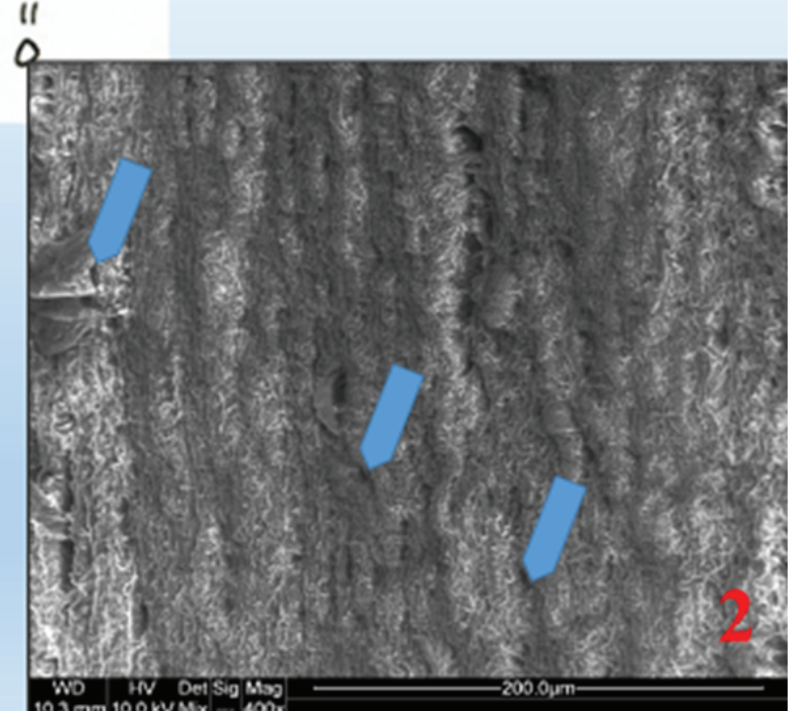

Figure 2.2: 1. A damaged, electrically charged fragment of the biological structure of the protein in an aortic valve of the heart, constituting the center of biomineralization; 2 . Collagen fibers of the mitral heart valve leaf with marked places where they separate from each other to form biomineralization centers. A valve from thevalve bank. Scanning microscope. 


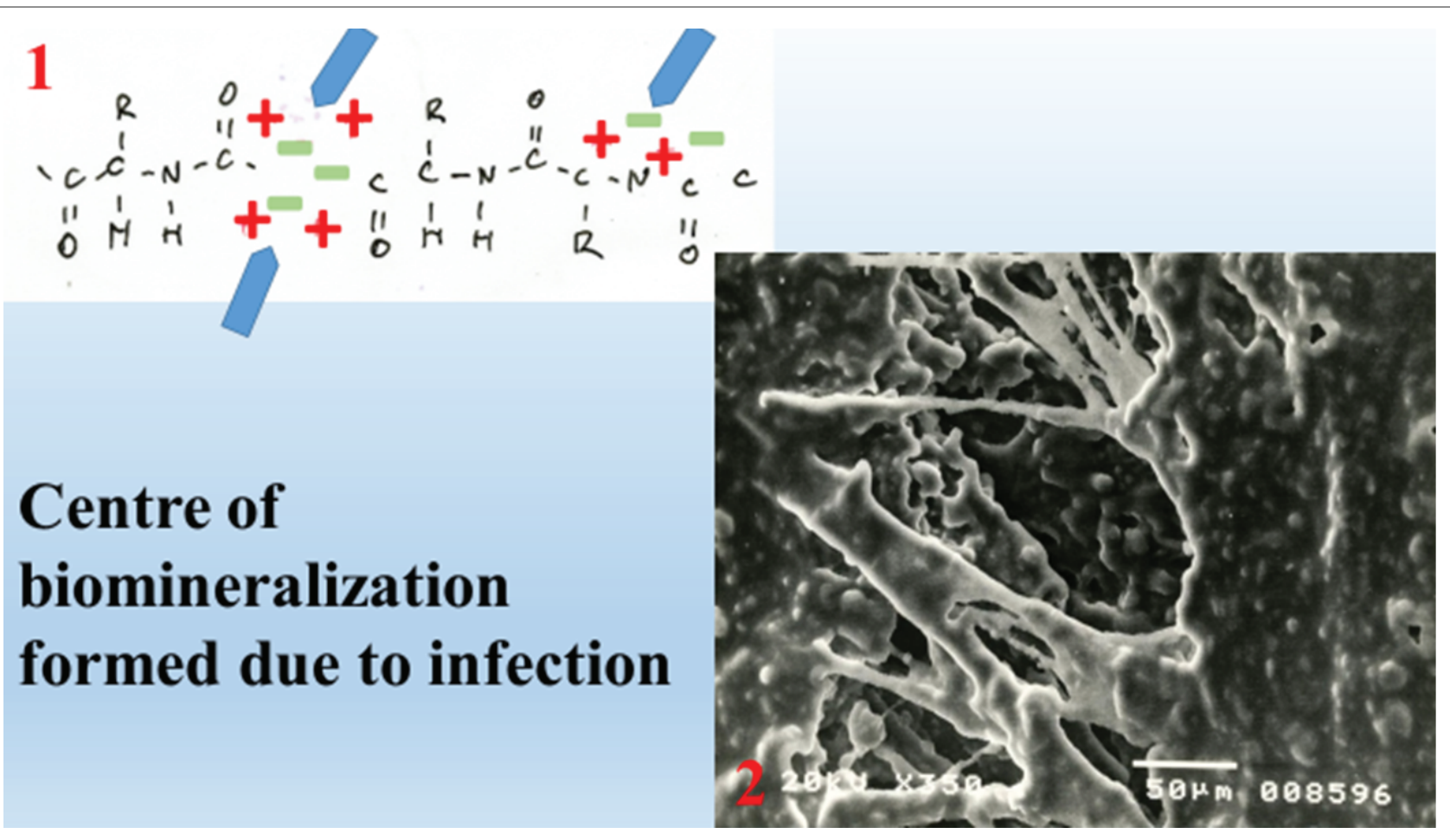

Figure 2.3: 1. Biological structure damaged by toxins produced by infecting microorganisms. "Erosions" are places (centers of mineralization) endowed with electric charges of damaged interatomic bonds of a biological structure. This is where the formation of deposits begins; 2 . Damaged endothelial surface reconstructed as a result of "self-healing".

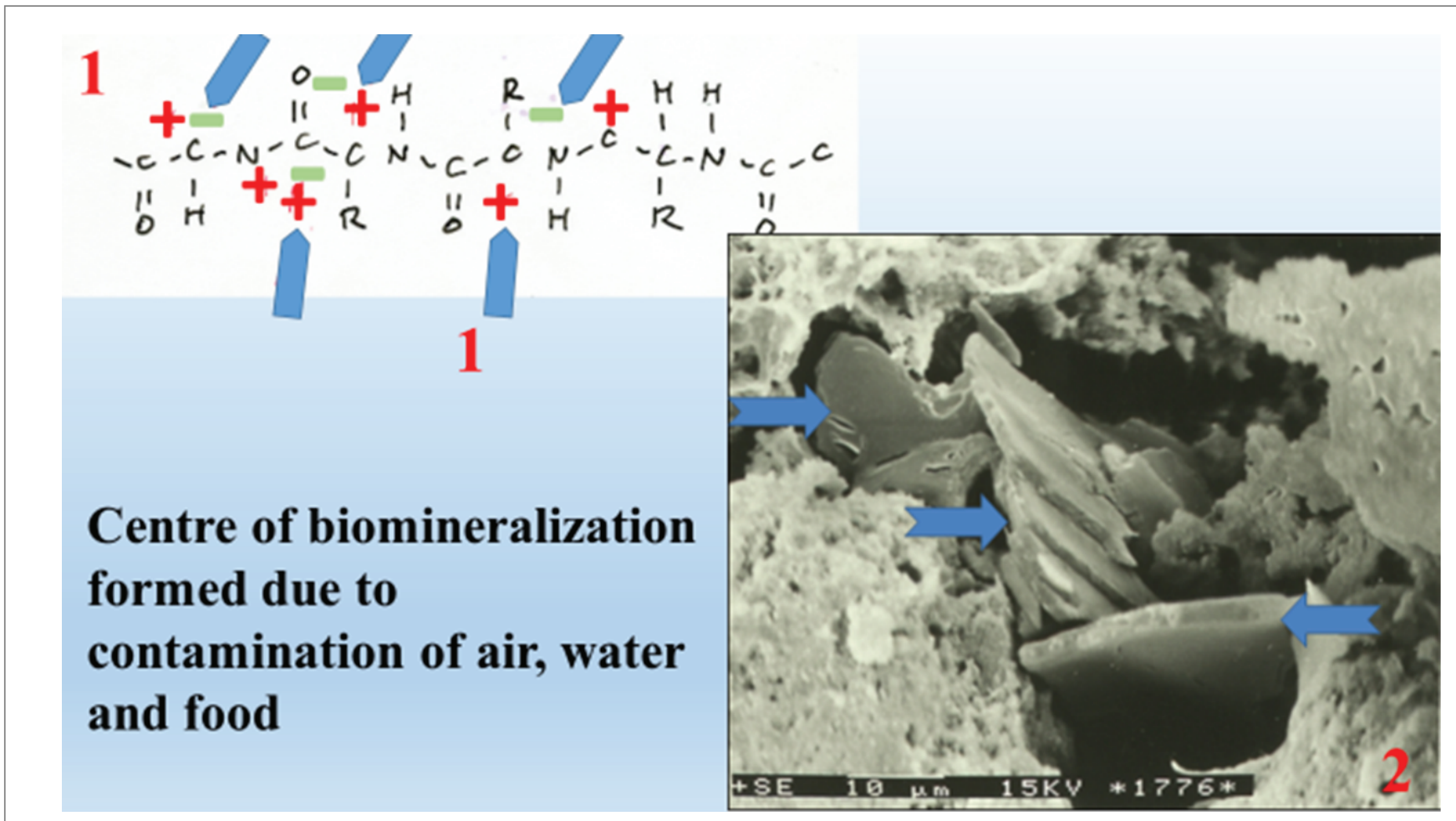

Figure 2.4: 1 . Destruction of the biological structure in the heart valve by air containing $\mathrm{SO}_{2}$ or another chemical agent penetrating into the blood; 2. Micrograph of the aortic valve with a damaged structure. Organic biomineralization, represented by plaques of cholesterol crystals, developed in the crystallization center formed as a result of the structure's destruction. Scanningmicroscope. 


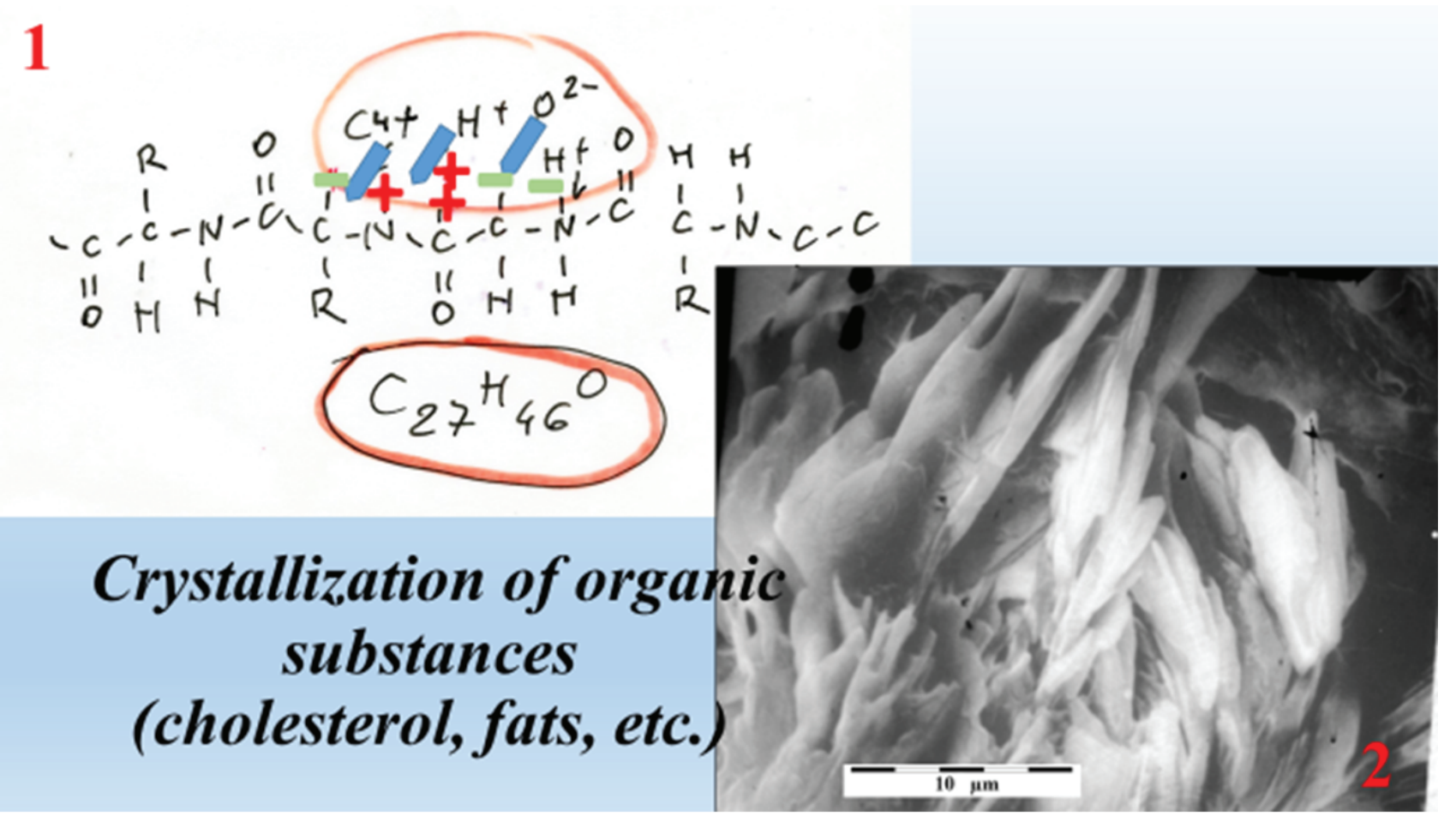

Figure 3.1: 1. Incorporation of the cholesterol structure into the crystallization center initiating the formation of a cholesterol deposit, e.g. in an artery; 2 . Cholesterol crystals on the inner wall of the artery in the base of the brain. Scanning microscope.

\section{Crystallization of inorganic substances}

If there are elevated amounts of calcium and phosphorus ions in the vicinity of the crystallization center, the process of so-called calcification begins (Figure 3.2). It contains calcium phosphates with various degrees of hydration and crystals of carbonate hydroxyapatite.

\section{Mixed organic-inorganic crystallization}

In the presence of charged organic and inorganic particles near the crystallization center, a deposit (e.g. so-called atherosclerotic plaque) is formed, built, for instance, of cholesterol and phosphates (Figures $1.1,1.2$ and 2.2).

\section{Dissolution of Arterial Biomineralization}

\section{Dissolution of organic substances crystallizing in tissues}

It is a complex procedure because organic mineralization can be multi-phase, i.e. composed of various components: fats, cholesterol, etc. Most often, the main ingredient is cholesterol. In vitro studies have shown $[32,33]$ that ethyl alcohol may be one of the solvents of cholesterol. Dissolution experiments on cholesterol-filled arteries have shown that some of the cholesterol was dissolved (Figure 4.1).

Crystallization from the solution used to dissolve the deposits allowed for the crystallization of cholesterol crystals with a size of up to $0.5 \mathrm{~mm}$.

\section{Dissolution of inorganic substances crystallizing in tissues}

Experiments on the dissolution of inorganic (phosphate) mineralization identified in arteries, but also in other tissues, were conducted with the use of various "solvents". One of the best despite unfavorable phosphate solubility product turned out to be water (Figure 4.2).

Dissolution of mixed organic-inorganic substances mineralizing the tissues

The most commonly recognized tissue mineralization, mixed organic-inorganic with different proportions of both components, requires complex solvents. Their use may determine the success of the dissolution process and directly improve the organ function.

\section{Blockers of Crystallization Centers}

One of the ways to combat tissue biomineralization may be the use of crystallization center blockers. These should be substances that bind to the damaged tissue in the center of crystallization, thanks to which the electric field will be eliminated, no longer "pulling" ions to mineralize the tissue.

The blocker particles should have a one-sided electric charge, thanks to which they will connect to the structure of the crystallization center (Figure 5). Their use should eliminate the electrical potential of the crystallization center, thereby eliminating the possibility of ion attachment and biomineralization.

Theoretical work on crystallization center blockers continues.

\section{Summary}

Various aspects of tissue biomineralization were presented. They maybe the basis of many new, important research works leading to both prevention of biomineralization and elimination of existing biomineralization. The importance of these studies cannot be overestimated. 


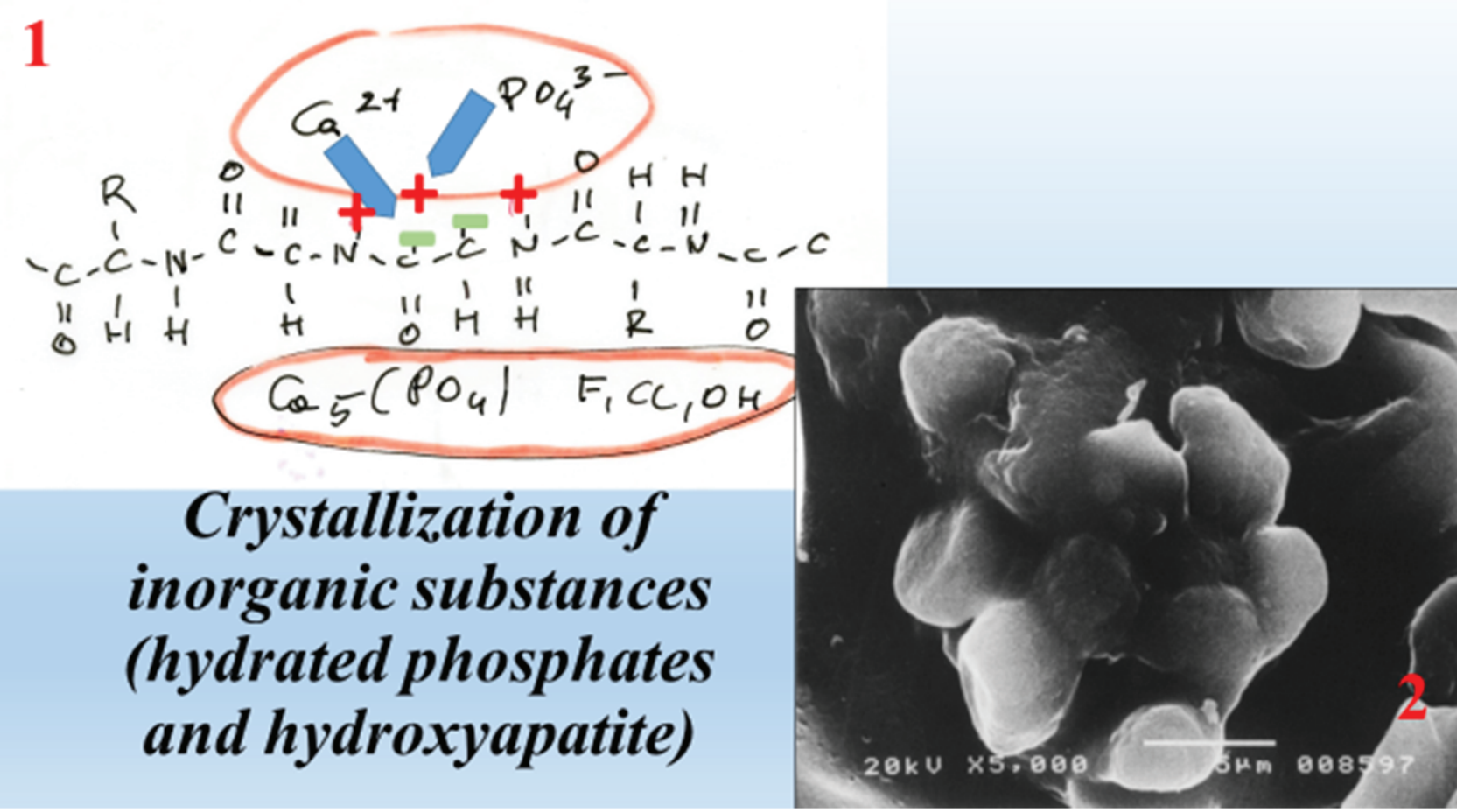

Figure 3.2: 1. Crystallization of calcium phosphates in a crystallization center formed in an artery; 2 . An aggregate of carbonate hydroxyapatite microcrystals on the surface of the artery. Scanning microscope.

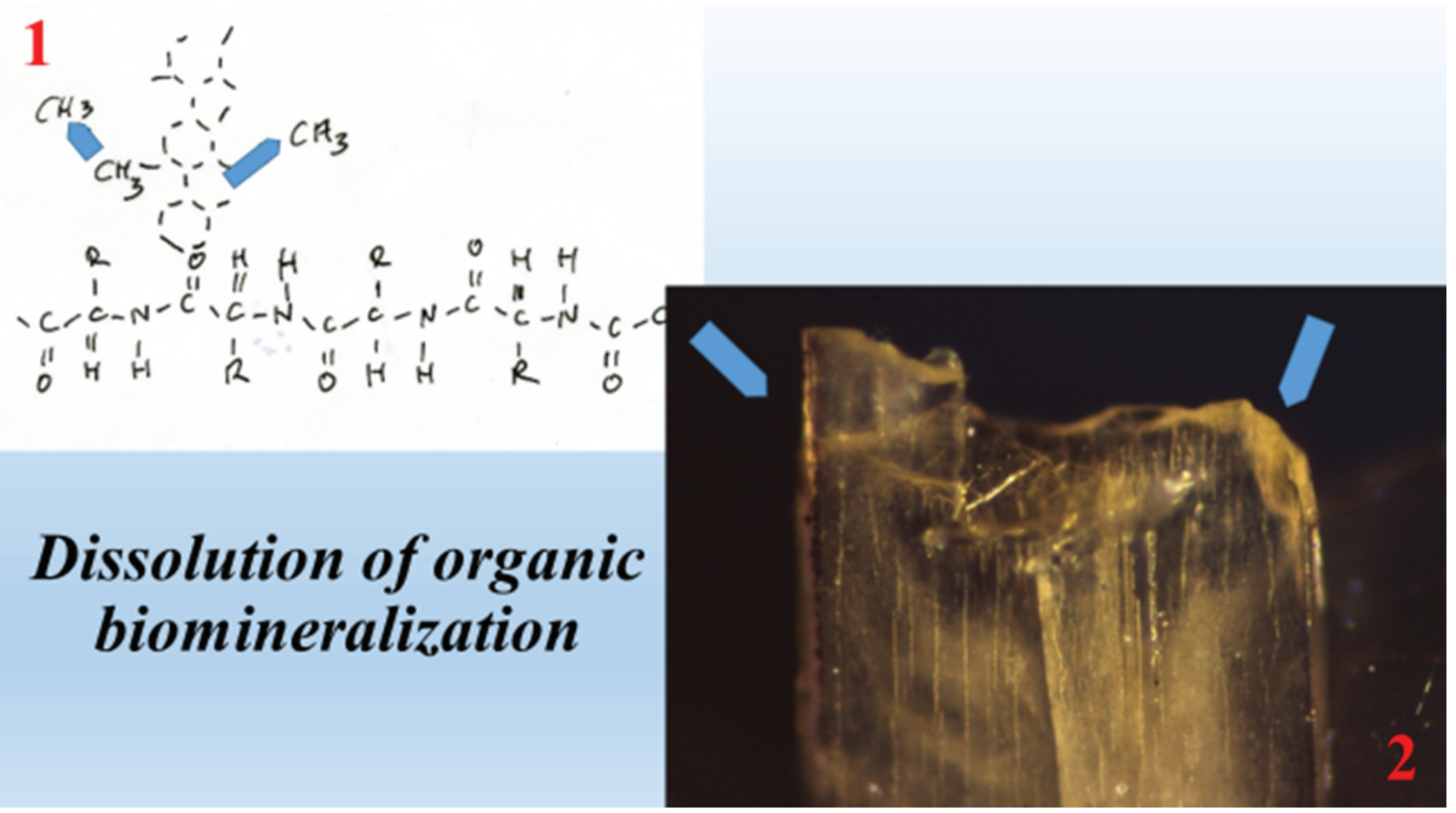

Figure 4.1: 1. Dissolving cholesterol from the femoral artery. Breaking the bonds of cholesterol particles from the center in the protein structure of the artery; 2 . Cholesterol crystal grown from the solvent passed through an artery filled with cholesterol. Digital microscope. 
1

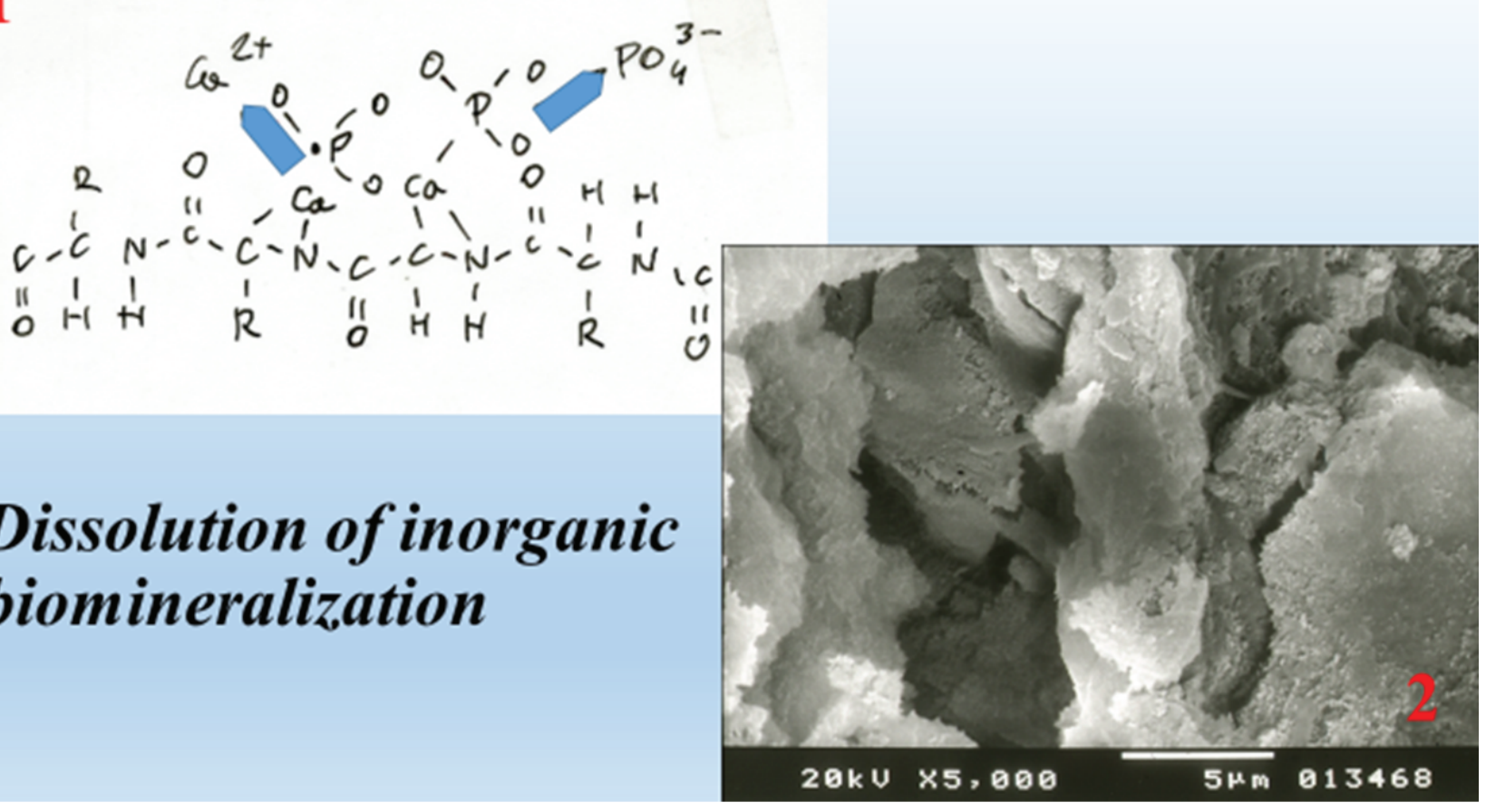

Figure 4.2: 1 . Diagram of detaching phosphate and calcium ions from the biological structure during dissolution of inorganic (phosphate) mineralization; 2. Degraded (partially dissolved) surface of fine crystalline phosphate mineralization. Scanning microscope.

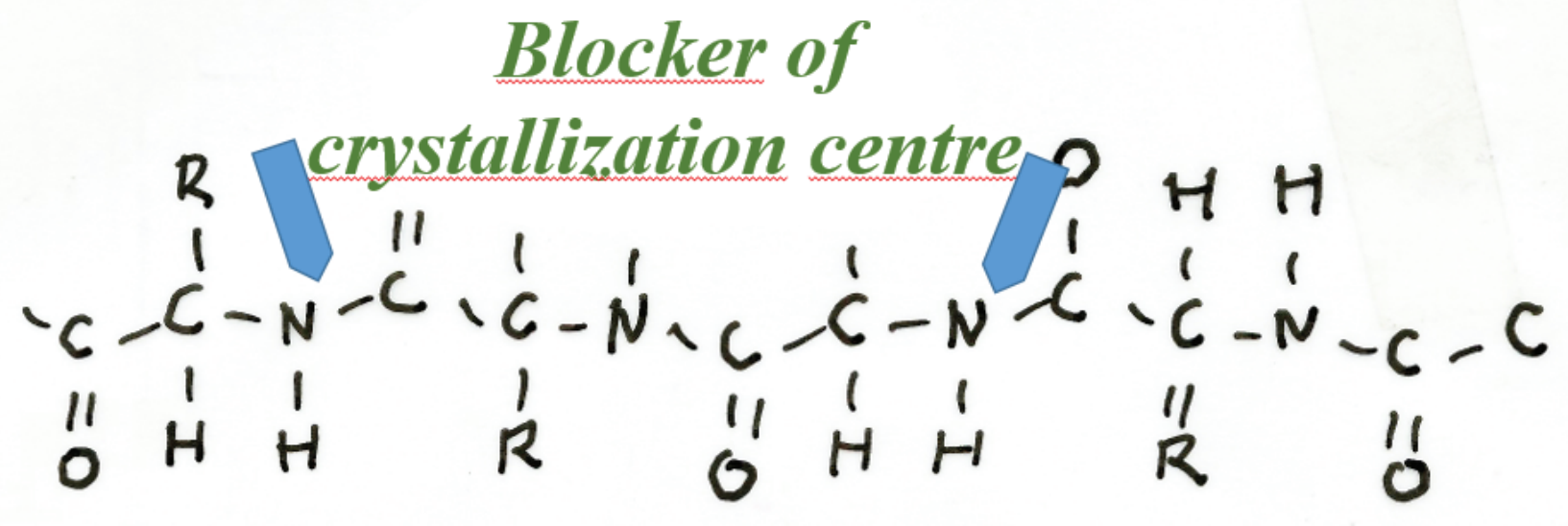

Figure 5: Graphical image of the role of crystallization center blocker eliminating a biomineralization center. 


\section{References}

1. Agatston AS, Janowitz WR, Hildner FJ, Zusmer NR, Viamonte M Jr, et al. (1990) Quantification of coronary artery calcium using ultrafast computed tomography. J Am Coll Cardiol 15: 827-832.

2. Bertazzo S, Gentleman E (2017) Aortic valve calcification: a bone of contention. Eur Heart J 38: 1189-1193.

3. Bloomfield P (2002) Choice of heart valve prosthesis. Heart 87: $583-$ 589.

4. Boughner DR, Thornton M, Dunmore-Buyze J, Holdsworth DW (2000) The radiographic quantitation of aortic valve calcification: implications for assessing bioprosthetic valve calcification in vitro. Physiol Meas 21: 409-416.

5. Budoff MJ, Lane KL, Bakhsheshi H, Mao S, Grassmann BO, et al. (2000) Rates of progression of coronary calcium by electron beam tomography. Am J Cardiol 86: 8-11.

6. Callister TQ, Raggi P, Cooil B, Lippolis NJ, Russo DJ (1998) Effect of HMG-CoA reductase inhibitors on coronary artery disease as assessed by electron-beam computed tomography. N Engl J Med 339: 1972-1978.

7. Ewe SH, Ng AC, Schuijf JD, van der Kley F, Colli A, et al. (2011) Location and severity of aortic valve calcium and implications for aortic regurgitation after transcatheter aortic valve implantation. Am J Cardiol 108: 1470-1477.

8. Gohlke-Barwolf C (2000) Anticoagulation in valvar heart disease: new aspects and management during non-cardiac surgery. Heart 86: $567-572$.

9. Enriquez-Sarano M (2002) Timing of mitral valve surgery. Heart 87: 79-85.

10. Haensig M, Lehmkuhl L, Rastan AJ, et al. (2012) Aortic valve calcium scoring is a predictor of significant paravalvular aortic insufficiency in transapical-aortic valve implantation. Eur J Cardiothorac Surg 41: 1234-1241.

11. Harbaoui B, Montoy $M$, Charles $P$, Boussel L, Liebgott $H$, et al. (2016) Aorta calcification burden: towards an integrative predictor of cardiac outcome after transcatheter aortic valve implantation. Atherosclerosis 246: 161-168.

12. Herzog CA, Ma JZ, Collins AJ (2002) Long-term survival of dialysis patients in the United States with prosthetic heart valves: should ACC/AHA practice guidelines on valve selection be modified? Circulation 105: 1336-1341.

13. Iivanainen AM, Lindroos M, Tilvis R, Heikkilä J, Kupari M (1996) Calcific degeneration of the aortic valve in old age: is the development of flow obstruction predictable? J Intern Med 239: 269-273.

14. Kapila A, Hart R (1986) Calcific cerebral emboli and aortic stenosis: detection of computed tomography. Stroke 17: 619-621.

15. Khetarpal V, Mahajan N, Madhavan R, Batra S, Mopala P, et al. (2009) Calcific aortic valve and spontaneous embolic stroke: a review of literature. J Neurol Sci 287: 32-35.

16. Kizer JR, Gefter WB, deLemos AS, Scoll BJ, Wolfe ML, et al. (2001) Electron beam computed tomography for the quantification of aortic valvular calcification. J Heart Valve Dis 10: 361-366.

17. Kleczyński P, Dziewierz A, Daniec M, Bagieński M, Rzeszutko L, et al. (2017) Impact of post-dilatation on the reduction of paravalvular leak and mortality after transcatheter aortic valve implantation. Kardiol Pol 75: 742-748.
18. Khalique OK, Hahn RT, Gada H, Nazif TM, Vahl TP, et al. (2014) Quantity and location of aortic valve complex calcification predicts severity and location of paravalvular regurgitation and frequency of post-dilation after balloon-expandable transcatheter aortic valve replacement. JACC Cardiovasc Interv 7: 885-894.

19. Koos R, Mahnken AH, Dohmen G, Brehmer K, Günther RW, et al. (2011) Association of aortic valve calcification severity with the degree of aortic regurgitation after transcatheter aortic valve implantation. Int J Cardiol 142-145.

20. Lindblom D, Lindblom U, Qvist J, Lundström H (1990) Long-term relative survival rates after heart valve replacement. J Am Coll Cardiol 15: 566-573.

21. Lindroos $M$, Kupari $M$, Valvanne J, Strandberg T, Heikkilä J, et al. (1994) Factors associated with calcific aortic valve degeneration in the elderly. Eur Heart J 15: 865-870.

22. Mako WJ, Vesely I (1997) In vivo and in vitro models of calcification in porcine aortic valve cusps. J Heart Valve Dis 6: 316-323.

23. Massel D, Little SH (2001) Risks and benefits of adding anti-platelet therapy to warfarin among patients with prosthetic heart valves: a meta-analysis. J Am Coll Cardiol 37: 569-578.

24. Mohler ER (2000) Are atherosclerotic processes involved in aorticvalve calcification? Lancet 356: 524-525.

25. Nagueh SF, Sun H, Kopelen HA, Middleton KJ, Khoury DS (2001) Hemodynamic determinants of the mitral annulus diastolic velocities by tissue Doppler. J Am Coll Cardiol 37: 278-285.

26. Otto CM, Lind BK, Kitzman DW, Gersh BJ, Siscovick DS (1999) Association of aortic-valve sclerosis with cardiovascular mortality and morbidity in the elderly. N Engl J Med 341: 142-147.

27. Otto CM, Kuusisto J, Reichenbach DD, Gown AM, O'Brien KD (1994) Characterization of the early lesion of 'degenerative' valvular aortic stenosis. Histological and immunohistochemical studies. Circulation 90: 844-853.

28. Otto CM, Burwash IG, Legget ME, Munt BI, Fujioka M, et al. (1997) Prospective study of asymptomatic valvular aortic stenosis. Clinical, echocardiographic, and exercise predictors of outcome. Circulation 95: 2262-2270.

29. Pawlikowski M (1987) Mineralizacja organizmu człowieka żyjącego (Mineralization of the living human organism). In: Wrocław Wyd. Polskiej Akademii Nauk 79: 12.

30. Pawlikowski M (1991) Mineralizacja guzów nowotworowych (Mineralization of cancer tumors). In: Szymański A (eds) Biomineralogia biomateriały. PWN Warszawa: 97-102.

31. Pawlikowski M (1993) Kryształy w organizmie człowiek (Crystals of human body). Kraków, Wydawnictwo i Drukarnia "Secesja". Prace Mineralogiczne 1: 32

32. Pawlikowski M (1999) Preliminary results of dissolution of substances mineralizing human arteries. Arch Mineralog 52: 195-210.

33. Pawlikowski M (2003) Minerals in human blood vessels and their dissolution in vitro. In: Skinner HCW, Berger AW (Eds) Geology and health. Oxford University Press, Oxford: 155-158.

34. Pawlikowski M (2010) Biomineralization of cancer tissues. In: Lach H (Eds) Molecular and Physiological Aspects of Regulatory Processes of the Organism. Wydawnictwo Abaton: 190-191.

35. Pawlikowski M (2013) Mineralization of lung cancer tumors. Aux Sci Arch Preserv Relicts Envir Engineer: 1-34. 
36. Pawlikowski M (2014) Osteoporosis as a source of tissue mineralization. Research on osteoporosis therapy and dissolution of arterial mineralization. J Life Sci 8: 610-625.

37. Pawlikowski M (2016) Biomineralogy of osteoporosis. Academia J Biotechnol 4: 1-8.

38. Pawlikowski M (2018) Problems of Biomineralization Dissolution in Human Arteries. Adv Card Res 1: 68-74.

39. Pawlikowski M (2019) Blockers for Crystallization Centers. EC Emerg Med and Critical Care 3: 1-5.

40. Pawlikowski M (2020) Artery biomineralization and its dissolution. ES J Cardiolog 1: 1006.

41. Pawlikowski M (2020) Tissue Biomineralization as a Mechanism Leading to Cancer Development. J Carcinog Mutagen 11: 347.

42. Pibarot P, Dumesnil JG (2000) Hemodynamic and clinical impact of prosthesis-patient mismatch in the aortic valve position and its prevention. J Am Coll Cardiol 36: 1131-1141.

43. Peter M, Hoffmann A, Parker C, Lüscher T, Burckhardt D (1993) Progression of aortic stenosis. Role of age and concomitant coronary artery disease. Chest 103: 1715-1719.

44. Pfitzner R, Barecka D, Pawlikowski M, Kopytek M, Rudnicka-Sosin L, et al. (2018) Influence of Cryopreservation on Structural, Chemical, and Immunoenzymatic Properties of Aortic Valve Allografts. Transplant Proc 50: 2195-2198.

45. Piper C, Körfer R, Horstkotte D (2000) Prosthetic valve endocarditis. Heart 85: 590-593.
46. Rumberger JA, Simons DB, Fitzpatrick LA, Sheedy PF, Schwartz RS (1995) Coronary artery calcium area by electron-beam computed tomography and coronary atherosclerotic plaque area. A histopathologic correlative study. Circulation 92: 2157-2162.

47. Ryś M, Hryniewiecki T, Michałowska I, Stokłosa P, Juraszek MR, et al. (2018) Quantitative estimation of aortic valve calcification in multislice computed tomography in predicting the development of paravalvular leaks following transcatheter aortic valve replacement. Postepy Kardiol Interwencyjnej 14: 85-89.

48. Sangiorgi G, Rumberger JA, Severson A, Edwards WD, Gregoire J, et al. (1998) Arterial calcification and not lumen stenosis is highly correlated with atherosclerotic plaque burden in humans: a histologic study of 723 coronary artery segments using nondecalcifying methodology. J Am Coll Cardiol 31: 126-133.

49. Stewart BF, Siscovick D, Lind BK, Gardin JM, Gottdiener JS, et al. (1997) Clinical factors associated with calcific aortic valve disease. Cardiovascular Health Study. J Am Coll Cardiol 29: 630-634.

50. Takamiya Y, Miura S, Sako H, Shirai K, Morishige N, et al. (2007) Pseudoaneurysm of the mitral-aortic intervalvular fibrosa following infective endocarditis in a patient with acute heart failure: a case report. J Cardiol 49: 353-356.

51. Pawlikowski M, Pfitzner R (1999) Mineralization of heart, (Mineralization of heart and big blood vessels). WydIGSMiE PAN Kraków: 142 